\section{International Scientific Journal Theoretical \& Applied Science}

p-ISSN: 2308-4944 (print) e-ISSN: 2409-0085 (online)

Year: 2017 Issue: $06 \quad$ Volume: 50

Published: $16.06 .2017 \quad$ http://T-Science.org
Ganiyu Adedayo Ajenikoko

Department of Electronic \& Electrical Engineering, Ladoke Akintola University of Technology, P.M.B. 4000,

Ogbomoso, Nigeria ajeedollar@gmail.com

Oluwadamilare Adeniyi Ashafa

Department of Electronic \& Electrical Engineering, Ladoke Akintola University of Technology, P.M.B. 4000,

Ogbomoso, Nigeria

SECTION 6. Metallurgy and energy.

\title{
DEVELOPMENT OF A FLOW RATE MODEL FOR RETROFITTING OF DAM FOR HYDROELECTRIC POWER GENERATION
}

\begin{abstract}
Retrofitting is the addition of an existing dam with hydroelectric power generation capabilities. It is a cost- effective way of increasing electricity production. Hydroelectric power generation is the electricity generated by hydropower and the production of electrical power through the use of the gravitational force of falling or flowing water. The cost of hydroelectricity is very low, making it competitive. A dam is used to collect water or for storage of water which can be evenly distributed between locations. Dam serves the purpose of retaining water, while other structures such as floodgates are used to manage or prevent water flow into specific land regions. The acute power outage in Ilorin, the capital city of Kwara state makes most organizations to produce below the optimal level. This research paper develops a flow rate model for retrofitting of ASA dam in Ilorin, Kwara state for hydroelectric power generation. The available theoretical powers, kinetic energy, potential theoretical energy as well as the weekly water levels of Asa Dam were used as input parameters for the development of the flow rate model. The flow rate model is then simulated in MATLAB environment to establish the linear relationship between the power and the falling height of the dam. The result of the model shows that the theoretical power varies linearly as the falling height of water in the dam while maintaining a constant flow rate of about $50 \mathrm{~m}^{3} / \mathrm{s}$.

Key words: Flow Rate, Retrofitting, Dams, Hydroelectric Generation, Water Turbine Generators, Theoretical Power, Penstock, Falling Height.

Language: English

Citation: Ajenikoko GA, Ashafa OA (2017) DEVELOPMENT OF A FLOW RATE MODEL FOR RETROFITTING OF DAM FOR HYDROELECTRIC POWER GENERATION. ISJ Theoretical \& Applied Science, 06 (50): 1-13.

Soi: http://s-o-i.org/1.1/TAS-06-50-1 Doi: crossef https://dx.doi.org/10.15863/TAS.2017.06.50.1
\end{abstract}

\subsection{Introduction}

Hydro-electric power plants convert the kinetic energy contained in falling water into electricity [[21], [22], [26], [27], [31]]. The energy in flowing water is ultimately derived from the sun and is therefore constantly being renewed. Energy contained in sunlight evaporates water from the ocean and deposits it on land in form of rain. Differences in land elevation result in rainfall runoff and allow some of the original solar energy to be captured as hydro-electric power [[28], [29], [30], [32]].

Most hydroelectric power comes from the potential energy of dammed water driving a water turbine and generator. In this case, the energy extracted from the water depends on the volume and on the difference in height between the source and the water's outflow. This height difference is called the head ' $h$ '. The amount of potential energy in water is proportional to the head. To obtain very high head, water for a hydraulic turbine may be run through a large pipe called a penstock [[5], [9], [12], [16], [25]].

\subsection{Advantages of hydropower}

Hydropower has the following advantages over other forms of energy production in terms of economics, social and environmental impacts [[1], [3], [2], [7], [8], [20], [23]]:

i. Hydropower is a form of clean renewable and sustainable energy as it makes use of the energy in water due to flow and available head without actually consuming the water itself. Unlike the burning of coal, oil and natural gas, it does not emit any atmospheric pollutants such as carbon dioxide, sulphur oxides, nitrous oxides or particulates such as ash. 


\begin{tabular}{|c|c|c|c|c|c|c|}
\hline Impact Factor: & $\begin{array}{l}\text { ISRA (India) } \\
\text { ISI (Dubai, UAF } \\
\text { GIF (Australia) } \\
\text { JIF }\end{array}$ & $\begin{array}{l}=1.344 \\
=0.829 \\
=0.564 \\
=1.500\end{array}$ & $\begin{array}{l}\text { SIS (USA) } \\
\text { PИНЦ (Russia } \\
\text { ESJI (KZ) } \\
\text { SJIF (Morocco }\end{array}$ & $\begin{array}{l}=\mathbf{0 . 9 1 2} \\
=\mathbf{0 . 2 3 4} \\
=\mathbf{3 . 8 6 0} \\
=\mathbf{2 . 0 3 1}\end{array}$ & $\begin{array}{l}\text { ICV (Poland) } \\
\text { PIF (India) } \\
\text { IBI (India) }\end{array}$ & $\begin{array}{l}=6.630 \\
=1.940 \\
=4.260\end{array}$ \\
\hline
\end{tabular}

ii. Hydropower schemes often have very long lifetimes and high efficiency levels. Operating costs per annum can be as low as $1 \%$ of the initial investment costs.

iii. Hydropower schemes often have more than one purpose. Hydropower through water storage can be used for flood control and can supply water for irrigation or consumption and dams constructed for hydropower can also be used for recreational purposes. Different forms of hydropower including reservoir, pumped storage and run-of-river systems of various sizes are available and can be used for different forms of electricity generation.

\subsection{Reasons for Retrofitting}

Some of the reasons for retrofitting are [[4], [6], [10], [11]]:

i. New operation purpose:- Dams could play a major role as storage for electricity generated from variable renewable energies (wind, solar, etc.). Economic benefits of this purpose were not considered adequately when assessing the viability..

ii. Mitigation: As climate change has become a major issue, electricity generated from hydropower can be a means of achieving emission reduction goals.

iii. Need for power generation: As some reservoirs are prone to sedimentation and contamination due to extensive use of fertilizers upstream, energy could also directly be used for the cleaning of the dam.

iv. Change in political priorities: With respect to altered political constellations, economic development status or other factors affecting the policy priorities might have changed.

Hydro schemes can be classified according to the level of power output. A summary of scheme classification is given in Table 1 below [[13], [14], [15], [17], [18], [19]].

\section{Classifications of Hydro schemes}

Table 1

\begin{tabular}{|c|c|c|c|}
\hline \multicolumn{2}{|c|}{ Classification } & Range & Purpose \\
\hline (i) & Pico & Up to $5 \mathrm{~kW}$ & $\begin{array}{l}\text { Small Local Generation-Simple off } \\
\text { Grid Domicile. }\end{array}$ \\
\hline (ii) & Micro & $5 \mathrm{~kW}$ to $100 \mathrm{~kW}$ & $\begin{array}{c}\text { Small Community off Grid } \\
\text { Generation. }\end{array}$ \\
\hline (iii) & Mini & $100 \mathrm{~kW}$ to $1 \mathrm{MW}$ & $\begin{array}{c}\text { Community Generation-either off or } \\
\text { On-Grid. }\end{array}$ \\
\hline (iv) & Small & $1 \mathrm{MW}$ to $10 \mathrm{MW}$ & Commercial Scale Generation \\
\hline $\begin{array}{l}\text { (v) } \\
\text { (vi) }\end{array}$ & $\begin{array}{l}\text { Medium } \\
\text { Large }\end{array}$ & $\begin{array}{c}10 \mathrm{MW} \text { to } 100 \mathrm{MW} \\
100 \mathrm{Mw}+\end{array}$ & Feeding Grid \\
\hline
\end{tabular}

\subsection{Materials and Method.}

\subsection{Development of Flow Rate Model}

Basic Assumptions in the development of flow rate model:

i. A set amount of flow is drawn off constantly to produce a constant amount of power

ii. Peak power is produced during the peak times of the day by considering daily releases into the peak values.

iii. A variable amount of flow is drawn off up to a maximum that the turbine can handle.

iv. Water is directed from the river to the intake.

v. The flow of water is decelerated by entering a settling tank or forebay in which particles suspended in high velocity flows can come to rest. The intake and forebay are often protected by a trash rack which does not allow large floating debris to pass into the penstock and turbine.

vi. The penstock carries the water at pressure to the turbine which is situated in the power house containing generation and control equipment.

vii. The water flow then exits the power house through the tailrace and back into the main water course.

Consider Figure 1 and 2 below: 


\begin{tabular}{l|lrl|l|ll} 
& ISRA (India) & $=\mathbf{1 . 3 4 4}$ & SIS (USA) & $=\mathbf{0 . 9 1 2}$ & ICV (Poland) & $=\mathbf{6 . 6 3 0}$ \\
Impact Factor: & ISI (Dubai, UAE) $=\mathbf{0 . 8 2 9}$ & PUHU (Russia) $=\mathbf{0 . 2 3 4}$ & PIF (India) & $=\mathbf{1 . 9 4 0}$ \\
& GIF (Australia) & $\mathbf{0 . 5 6 4}$ & ESJI (KZ) & $=\mathbf{3 . 8 6 0}$ & IBI (India) & $\mathbf{4 . 2 6 0}$
\end{tabular}

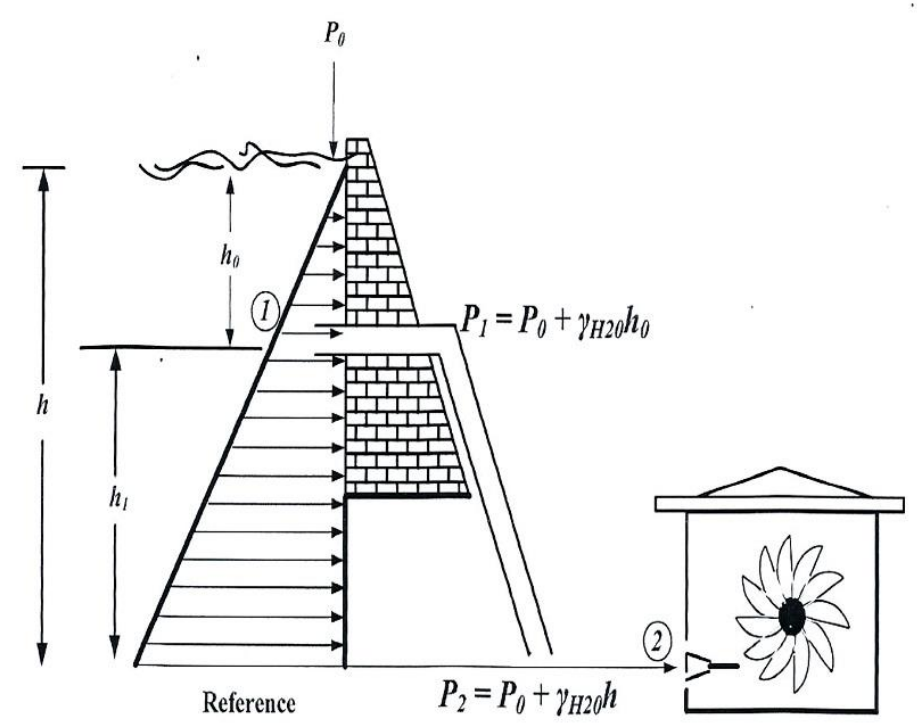

Figure 1 - Variable Pressure by water height.

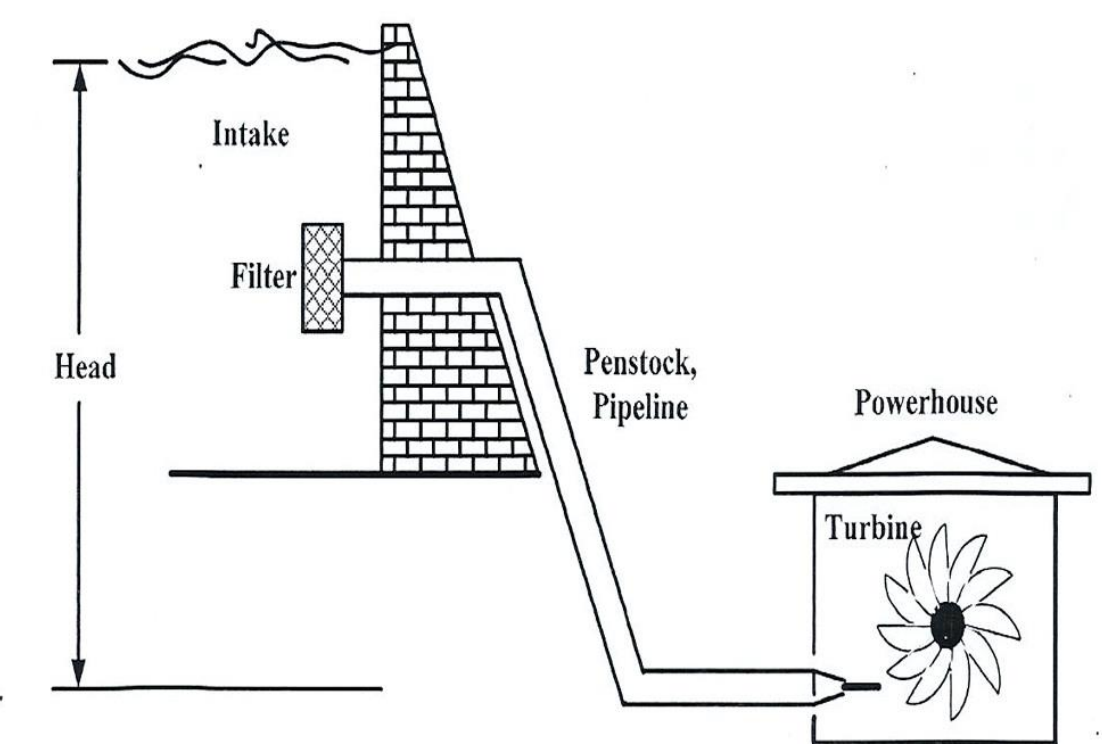

Figure 2 - Hydroelectric Power Generation.

For a volume of fluid which is not in motion or is in a state of constant motion, Newton's Laws states that it must have zero net force on it i.e. the forces going up must equal the forces going down. This force balance is called the hydrostatic balance. The net force over one point is due to the fluid weight. The linear variation of pressure by water height is given by.

$$
P=P_{a}+\gamma h
$$

Where $\gamma=$ Specific Weight of the fluid

$\mathrm{P}_{\mathrm{o}}=$ Atmospheric pressure

$\mathrm{h}=$ Height

The velocity at the intake of the system point 1 is the same as the velocity in point 2 , but not necessarily the same at the turbine input. This is due to the use of nozzles at the pipe end in some cases. The continuity equation states that for steady flow in a pipeline, the weight flow rate (weight of fluid passing a given station per unit time) is the same for all locations of the pipe.

The law of conservation of energy states that energy can neither be created nor destroyed. This means that the total energy of a system remains constant. The total energy includes potential energy due to elevation and pressure and also kinetic energy due to velocity. Considering the system, the total energy is

$$
E_{t}=W H_{1}+W \frac{P_{1}}{\gamma}+\frac{1}{2} \frac{W}{g} v_{1}^{2}=\text { Constant }
$$




\begin{tabular}{|c|c|c|c|c|c|c|}
\hline Impact Factor: & $\begin{array}{l}\text { ISRA (India) } \\
\text { ISI (Dubai, UAE } \\
\text { GIF (Australia) } \\
\text { JIF }\end{array}$ & $\begin{array}{l}=1.344 \\
=0.829 \\
=0.564 \\
=1.500\end{array}$ & $\begin{array}{l}\text { SIS (USA) } \\
\text { PИНЦ (Russia) } \\
\text { ESJI (KZ) } \\
\text { SJIF (Morocco) }\end{array}$ & $\begin{array}{l}=0.912 \\
=0.234 \\
=3.860 \\
=\mathbf{2 . 0 3 1}\end{array}$ & $\begin{array}{l}\text { ICV (Poland) } \\
\text { PIF (India) } \\
\text { IBI (India) }\end{array}$ & $\begin{array}{l}=6.630 \\
=1.940 \\
=4.260\end{array}$ \\
\hline
\end{tabular}

$W H_{1}+W \frac{P_{1}}{\gamma}+\frac{1}{2} \frac{W}{g} v_{1}^{2}=W H_{2}+W \frac{P_{2}}{\gamma}+\frac{1}{2} \frac{W}{g} v_{2}^{2}$

Where $\mathrm{V}_{1}, \mathrm{~V}_{2}=$ velocities at the two points

$\mathrm{H}_{1}=$ Losses in pipe

Equation (3) is known as Bernoulli's Equation.

For a pipe in which fluid is flowing with a weight flow rate, $\mathrm{W}$ that has units of weight per unit time, the pipe has two different-size cross-sectional areas identified by stations 1 and 2 . The continuity equation states that if no fluid is added or withdrawn from the pipeline between stations 1 and 2, then the weight flow rate at stations 1 and 2 must be equal, i.e.

$$
\begin{aligned}
W_{1} & =W_{2} \\
\gamma A_{1} V_{1} & =\gamma A_{2} V_{2}
\end{aligned}
$$

The power available from falling water can be expressed as

$$
P_{t h}=\rho q g h
$$

where

$\mathrm{P}_{\text {th }}=$ available theoretical power

$\rho=$ density $\left(\mathrm{kg} / \mathrm{m}^{3}\right)\left(\sim 1000 \mathrm{~kg} / \mathrm{m}^{3}\right.$ for water $)$

$\mathrm{q}=$ water flow $\left(\mathrm{m}^{3} / \mathrm{s}\right)$

$\mathrm{g}=$ acceleration due to gravity $\left(9.81 \mathrm{~ms}^{-2}\right)$

$\mathrm{h}=$ falling height, head $(\mathrm{m})$

\section{Efficiency}

Due to energy loss, the available power will be less than the theoretically available power. The practically available power is expressed as:

where

$$
P_{a}=\mu \rho q g h
$$

$\mathrm{P}_{\mathrm{a}}=$ power available $(\mathrm{W})$

$\mu=$ efficiency (in general in the range 0.75 to

$\mathrm{g}=$ acceleration due to gravity $\left(9.81 \mathrm{~m} / \mathrm{s}^{2}\right)$

$\mathrm{h}=$ falling height, head (m)

\section{Energy from Hydropower}

The potential theoretical energy in a volume of elevated water can be expressed as:

$$
W=\rho V g h
$$

Where

$\mathrm{W}=\operatorname{energy}(\mathrm{J})$

$\mathrm{V}=$ volume of water $\left(\mathrm{m}^{3}\right)$

$\mathrm{g}=$ acceleration due to gravity $\left(9.81 \mathrm{~m} / \mathrm{s}^{2}\right)$

$\mathrm{h}=$ falling height, head $(\mathrm{m})$

\section{Capacity Factor}

Capacitor factor (CF) is the ratio of actual output to its potential output over a period of time.

$$
C . F=\frac{\left(\text { Energy Generated per year }\left(\frac{k W h}{\text { year }}\right)\right)}{(\text { Installed Capacity } k W) \times 8760^{\text {hour }} / \text { year }}
$$

$$
\begin{aligned}
& \text { Potential energy of water } \\
& P . E=M \times g \times H
\end{aligned}
$$

\section{Kinetic energy of water}

$$
K . E=1 / 2 \times M \times C^{2}
$$

where:

$\mathrm{g}$ is the acceleration due to gravity $\left(9.81 \mathrm{~m} / \mathrm{s}^{2}\right)$,

$\mathrm{H}$ is the Effective Pressure Head of water across the turbine $(\mathrm{m})$.

$\mathrm{C}$ is the jet velocity of water at the intake of the turbine blade $(\mathrm{m} / \mathrm{s})$.

and:

$$
\text { jet velocityC }=\sqrt{2 g H} \text {, }
$$

The weekly water level reading of Asa Dam collated over a period of thirty-six weeks were used. The discharge over the dam can be calculated from:

$$
Q=1.8(L-0.2 h) h^{1.5}
$$

where $Q$ is the discharge in $\mathrm{m}^{3} / \mathrm{h}$.

$\mathrm{L}$ is the length of the water in ' $\mathrm{m}$ '.

$\mathrm{H}$ is the height of the level of water flowing over the veir.

The amount of water flow rate is expressed as:

$$
F . R=\frac{\pi}{4} d^{2} \sqrt{2 g Z}
$$

Where: $\mathrm{Z}$ is the specific head height in meters, $\mathrm{d}$ is distance between dams.

\section{Simulation}

The weekly water level readings of the dam over a period of thirty six weeks were used as simulation parameters for the development of the flow rate model for Asa Dam using MATLAB codes.

\subsection{Results and Discussions}

The measured water level in the dam within the thirty six weeks study period is illustrated in Figure 1. Figure 2 shows the variation of the time and the date for the dam for the study period.

On April 15, 2016, the measured water level was $1.1 \mathrm{~cm}$ at 15.20 hours of the day while the measured water level at 14.10 hours on April 22, 2016 was 1.8 $\mathrm{cm}$. The monthly flow rate of the dam in April 2016 was $1.511 \mathrm{~m}^{3} / \mathrm{s}$ with a percentage flow rate of $5 \%$. The percentage flow rate varied inversely as the monthly flow rate throughout the month of April 2016. The least and highest percentage flow rate of $5 \%$ and $95 \%$ gave corresponding flow rates of 1.511 $\mathrm{m}^{3} / \mathrm{s}$ and $0.29 \mathrm{~m}^{3} / \mathrm{s}$ respectively as illustrated in Figure 3.

The measured water level fluctuates between 2.1 $\mathrm{cm}$ and $2.6 \mathrm{~cm}$ in the month of May 2016. In this month, the least water level of $2.0 \mathrm{~cm}$ was measured on the dam on May 16, 2016 at exactly 15.05 hours of the day while the highest water level of $2.6 \mathrm{~cm}$ was measured on the dam on May 21, 2016 at 14.34 hours of that day. Figure 4 shows the relationship between the percentage flow rate and the monthly flow rate for May 2016. In this year, a least 
percentage flow rate of $5 \%$ gave a monthly flow rate of $1.236 \mathrm{~m}^{3} / \mathrm{s}$ while the highest percentage flow rate of $99 \%$ gave a monthly flow rate of $0.09 \mathrm{~m}^{3} / \mathrm{s}$ indicating an inverse relationship between the time parameters.

In the month of June, 2016, the measured water level of the dam fluctuated between $2.1 \mathrm{~cm}$ on June 17,2016 at 14.13 hours of the day to $2.9 \mathrm{~cm}$ on June 21,2016 at exactly 14.23 hours of the day. This is because appreciable level of rainfall was recorded and experienced during this month of June, 2016. In June 2016, a percentage flow rate of $25 \%$ gave a monthly flow rate of $1.21 \mathrm{~m}^{3} / \mathrm{s}$ with an inverse correlation between the two parameters as shown in Figure 5.

On July 6, 2016, $2.8 \mathrm{~cm}$ was recorded as the measured water level of the dam during the 12.35 hours of the day. The water level fluctuated throughout this month between $2.7 \mathrm{~cm}$ and $3.2 \mathrm{~cm}$ on July 10, 2016 and July 21, 2016 during the 13.43 hours and 14.37 hours of those days respectively. This is because more rainfalls were experienced during this month as well. Figure 6 shows the flow rate for the month of July, 2016. In this month, a percentage flow rate of $75 \%$ corresponds to a flow rate of $0.16 \mathrm{~m}^{3} / \mathrm{s}$ even though, the percentage flow rate increases as the monthly flow rate decreases.

The least measured water level of $2.9 \mathrm{~cm}$ was recorded on August 13, 2016 during the 15.39 hours of the day while the highest water level of $10.3 \mathrm{~cm}$ was measured on August 24, 2016 during the 17.25 hours of the day. This is because this month of August marked a month of continuous rainfall during the year. The rainfalls experienced during this month lasted for a longer period of time and it was consistent. The percentage flow rates of $20 \%, 30 \%$ and $40 \%$ gave corresponding monthly flow rates of $1.91 \mathrm{~m}^{3} / \mathrm{s}, 1.74 \mathrm{~m}^{3} / \mathrm{s}$ and $1.51 \mathrm{~m}^{3} / \mathrm{s}$ respectively for August, 2016 thus showing an inverse relationship between the two parameters as shown in Figure 7.

The month of September 2016 witnessed or experienced a reduction in level of rainfall compared to the previous months . On September 3, 2016, the measured water level of the dam was $2.4 \mathrm{~cm}$. the least measured water level was $1.7 \mathrm{~cm}$ on September 12, 2016 during the 15.27 hours of the day while the 15.23 hours of September 29, 2016 witnessed the highest measured water level of $6.8 \mathrm{~cm}$ even though, the measured water levels fluctuated throughout this month. Figure 8 illustrates the flow rate for September 2016. The percentage flow rate and the monthly flow rates are inversely related as seen in Figure 8 .
October 2016 witnessed a prolonged shortage of rainfall because the least measured water level of the dam was $1.1 \mathrm{~cm}$ on October 27, 2016 during the $20 . .33$ hours of the day while the highest measured water level of $4.2 \mathrm{~cm}$ was recorded on October 4, 2016 during the 18.26 hours of the day.. The correlation between the percentage flow rate and the monthly flow rate for the month of October 2016 is shown in Figure 9.

The measured water levels in the dam during the month of November reduced appreciably probably because this month marked an acute shortage of rainfall. The least water level measured on the dam was $0.7 \mathrm{~cm}$ on November 5, 2016 during the 16.36 hours of the day while the highest measured water level of the dam was $1.3 \mathrm{~cm}$ on November 9, 2016 during the 17.20 hours of that day simply because this month marked a period of regular rainfall. Figure 10 illustrates the relationship between the percentage flow rate and the monthly flow rate for the month of November 2016. In this month, the least monthly flow rate of $1.43 \mathrm{~m}^{3} / \mathrm{s}$ was recorded while the highest monthly flow rate of $0.87 \mathrm{~m}^{3} / \mathrm{s}$ was recorded with percentage flow rate of $5 \%$ and $99 \%$ respectively. An inverse correspondence exists between the two parameters as well.

Figure 11 shows the total monthly flow rate for the dam. The percentage flow rates also vary inversely as the total monthly flow rate for the dam for the study period. The least total monthly flow rate is $4.06 \mathrm{~m}^{3} / \mathrm{s}$ which corresponds to a highest percentage flow rate of $99 \%$.

Figure 12 shows the variation of the power with the falling heights. The height undergoes variations as the flow rate remains approximately constant. The falling height of the water dam was $2 \mathrm{~m}$ at a theoretical power of $100 \mathrm{~W}$. The power in this case varies linearly as the falling height. Thus, at a power of $600 \mathrm{~W}$, the falling height was $12 \mathrm{~m}$. Figure 13 shows variation of the flow rate with the falling height of the water dam. The flow rate varies inversely as the height of the falling water.. A linear flow rate model of the form $y=0.3014 x+0.1032$ was developed for retrofitting of dam for hydroelectric power generation.

$$
\begin{gathered}
y=0.3014 x+0.1032 \\
p=q h+c
\end{gathered}
$$

Where:

$\mathrm{y}=$ flow rate model

$\mathrm{x}=$ falling height of water in the dam

The model will read the input parameters and calculate the flow rate of the system. 


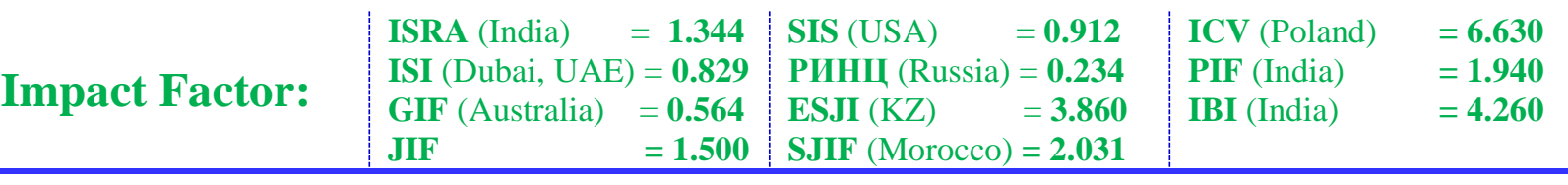

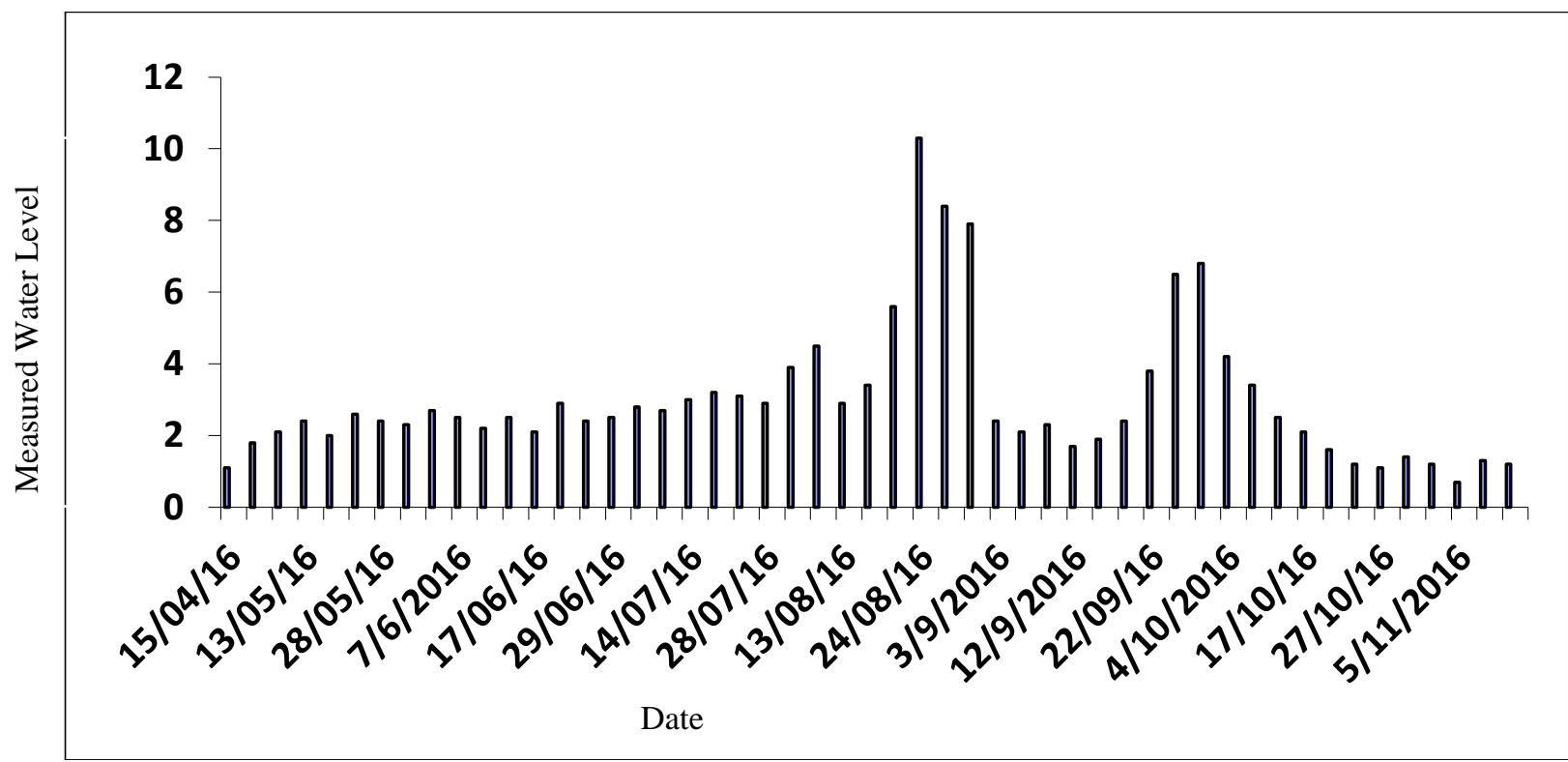

Figure 1 - Measured Water Level versus Date.

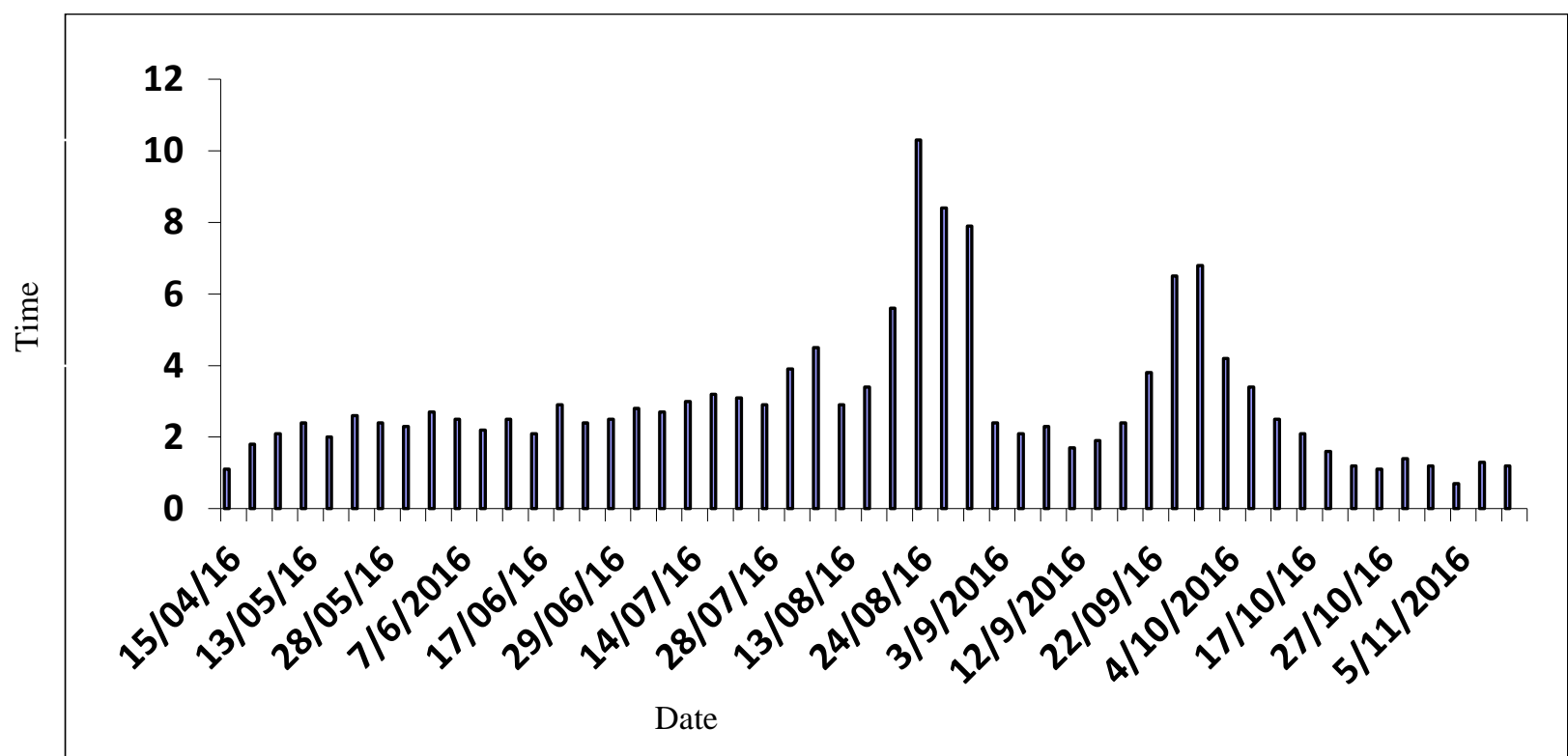

Figure 2 - Time versus Date. 


\begin{tabular}{|c|c|c|c|c|c|c|}
\hline Impact Factor: & $\begin{array}{l}\text { ISRA (India) } \\
\text { ISI (Dubai, UAE } \\
\text { GIF (Australia) } \\
\text { JIF }\end{array}$ & $\begin{array}{l}=1.344 \\
=0.829 \\
=0.564 \\
=1.500\end{array}$ & $\begin{array}{l}\text { SIS (USA) } \\
\text { PИНЦ (Russia) } \\
\text { ESJI (KZ) } \\
\text { SJIF (Morocco) }\end{array}$ & $\begin{array}{l}=0.912 \\
=0.234 \\
=3.860 \\
=2.031\end{array}$ & $\begin{array}{l}\text { ICV (Poland) } \\
\text { PIF (India) } \\
\text { IBI (India) }\end{array}$ & $\begin{array}{l}=6.630 \\
=1.940 \\
=4.260\end{array}$ \\
\hline
\end{tabular}

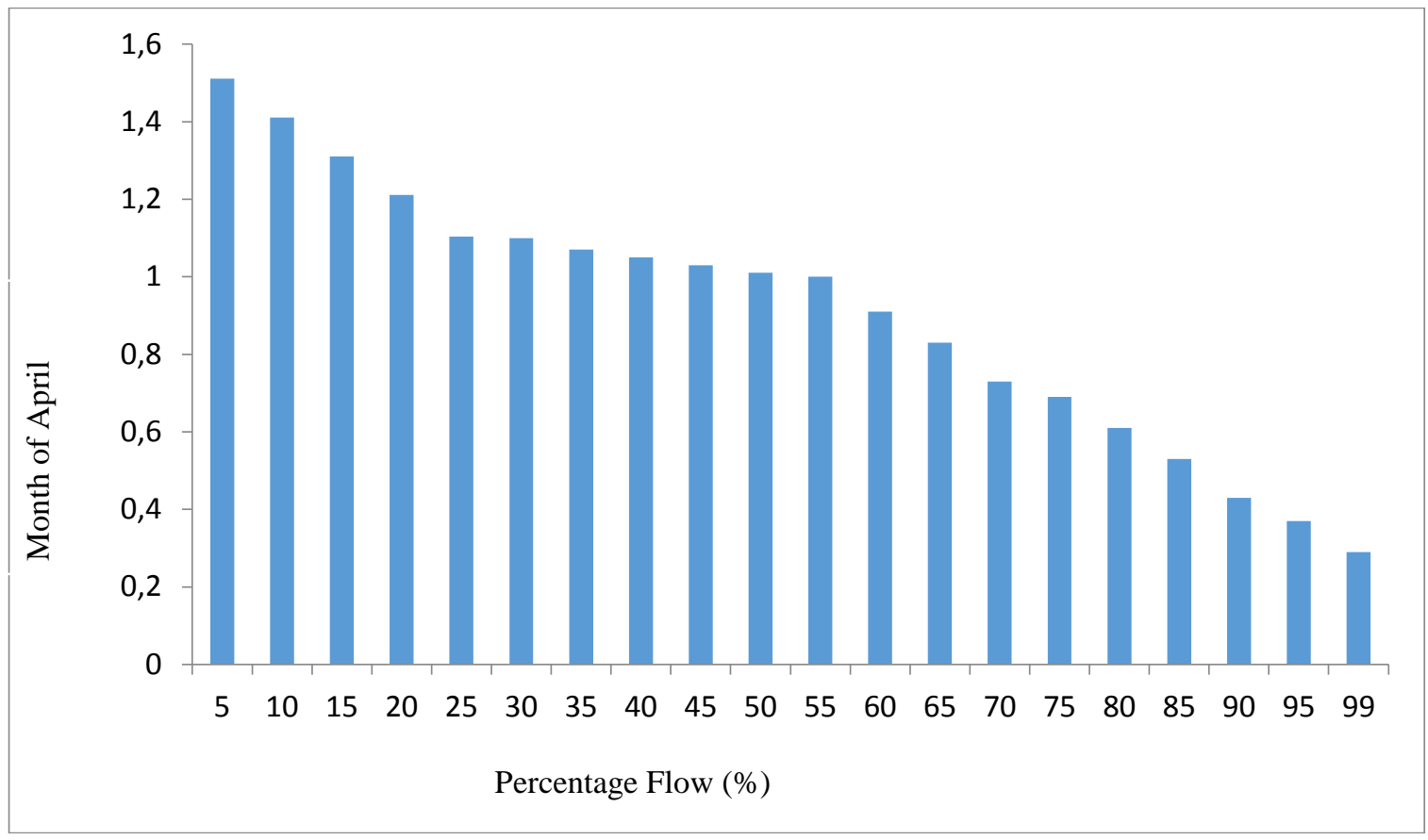

Figure 3 - Flow rate for April.

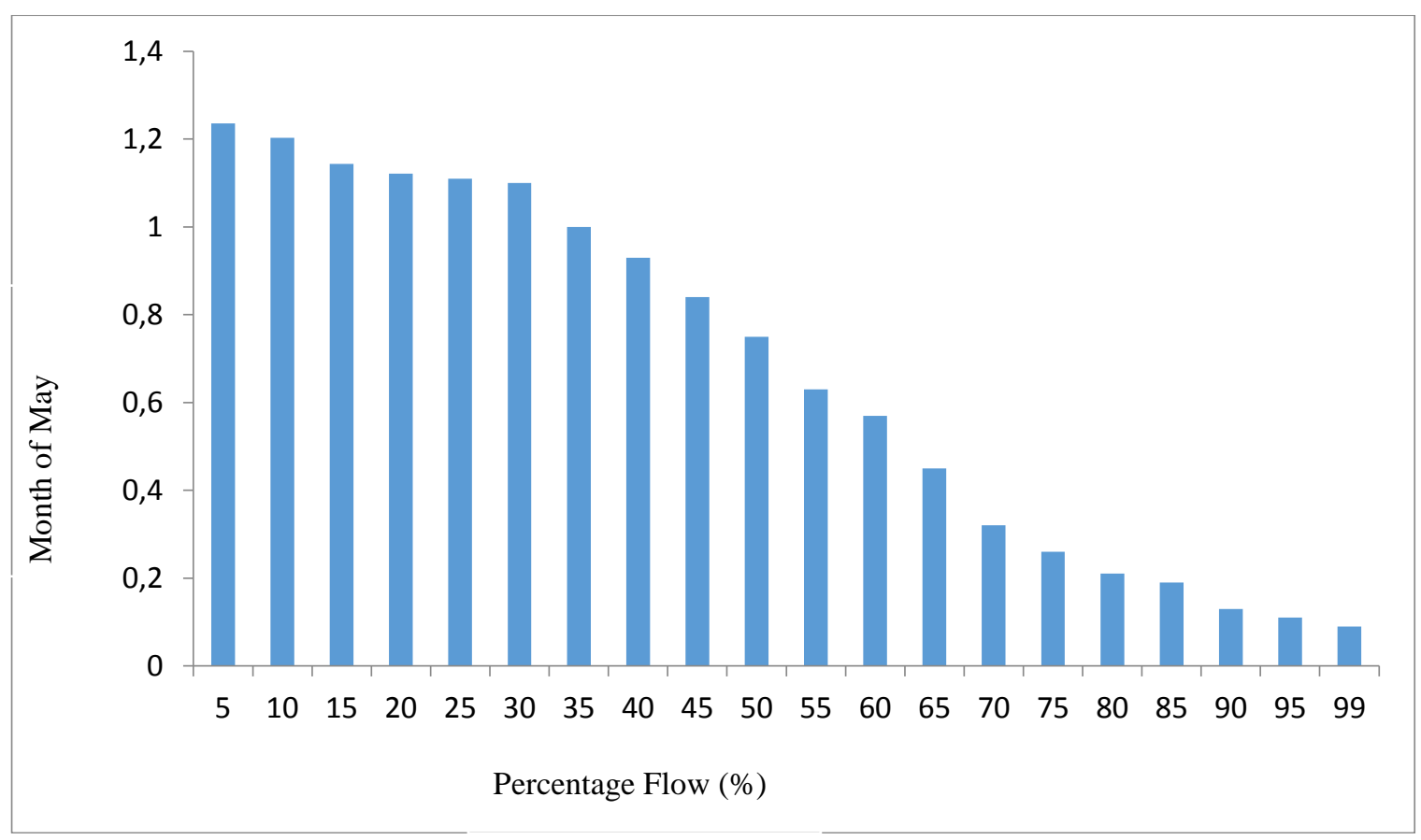

Figure 4 - Flow rate for May. 


\begin{tabular}{l|lr|ll|ll} 
& ISRA (India) & $=\mathbf{1 . 3 4 4}$ & SIS (USA) & $=\mathbf{0 . 9 1 2}$ & ICV (Poland) & $=\mathbf{6 . 6 3 0}$ \\
Impact Factor: & ISI (Dubai, UAE) $=\mathbf{0 . 8 2 9}$ & PUHL (Russia) & $=\mathbf{0 . 2 3 4}$ & PIF (India) & $=\mathbf{1 . 9 4 0}$ \\
& GIF (Australia) & $=\mathbf{0 . 5 6 4}$ & ESJI (KZ) & $=\mathbf{3 . 8 6 0}$ & IBI (India) & $\mathbf{4 . 2 6 0}$
\end{tabular}

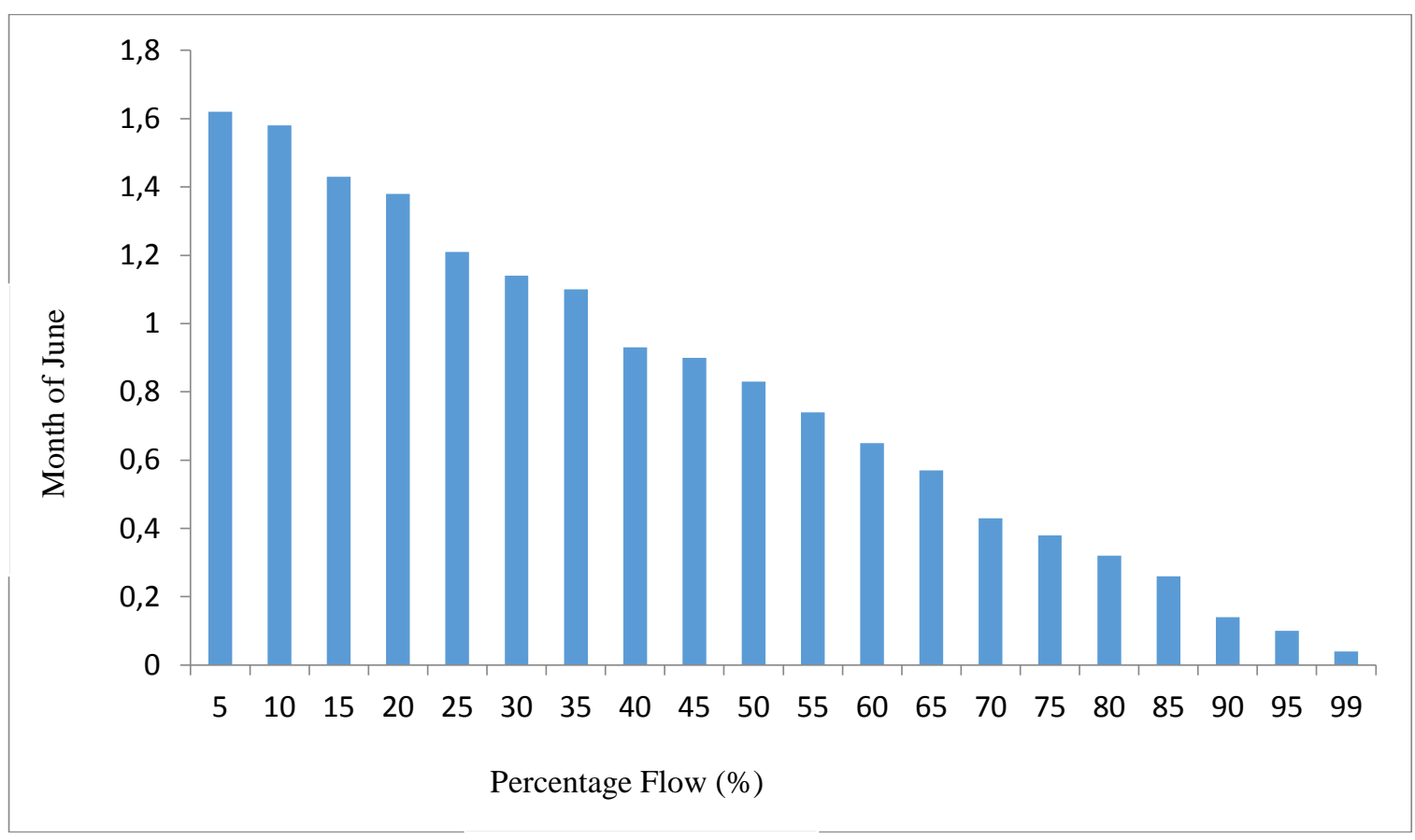

Figure 5 - Flow rate for June.

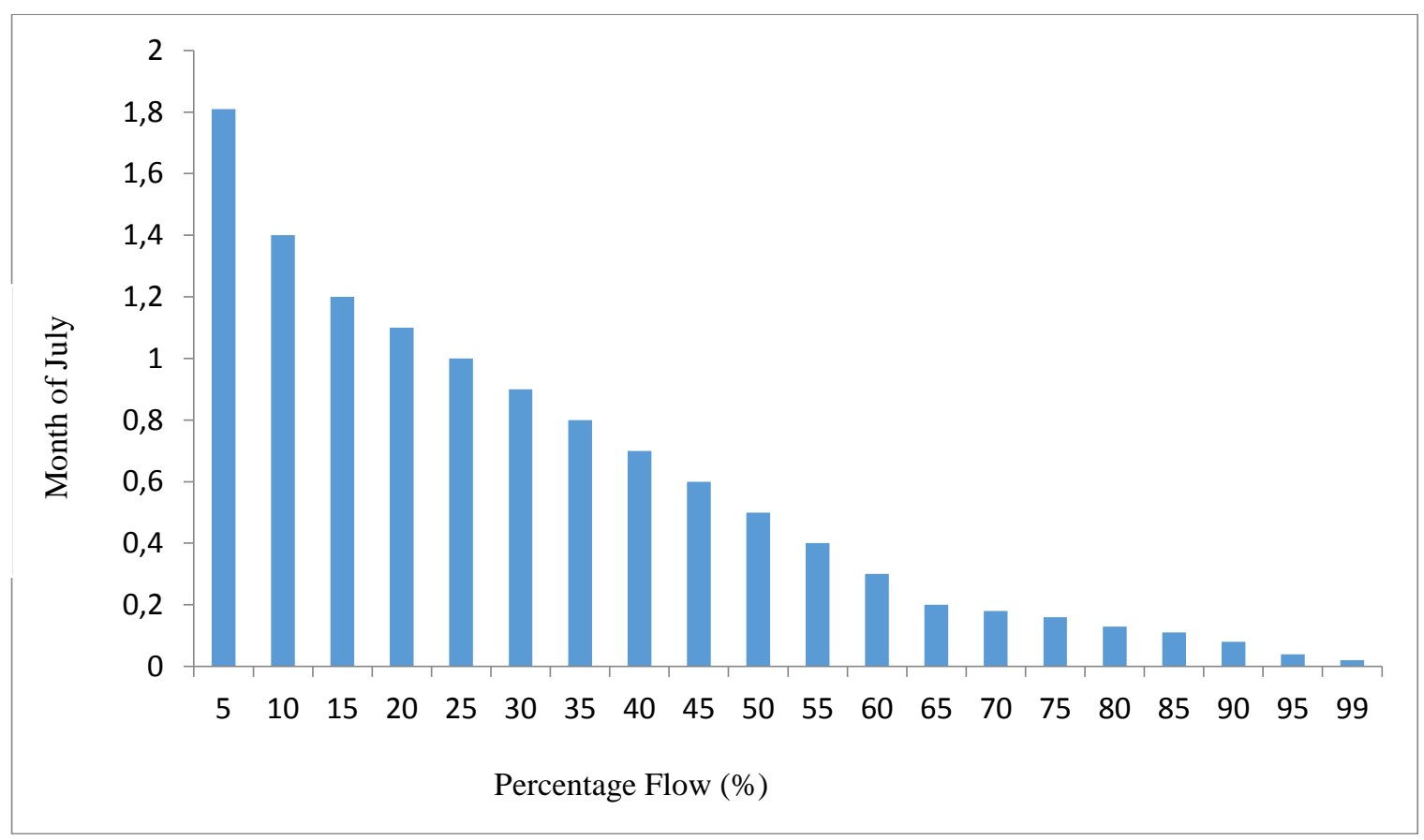

Figure 6 - Flow rate for July. 


\begin{tabular}{l|lr|ll|ll} 
& ISRA (India) & $\mathbf{1 . 3 4 4}$ & SIS (USA) & $=\mathbf{0 . 9 1 2}$ & ICV (Poland) & $=\mathbf{6 . 6 3 0}$ \\
Impact Factor: & ISI (Dubai, UAE) $=\mathbf{0 . 8 2 9}$ & PUHL (Russia) $=\mathbf{0 . 2 3 4}$ & PIF (India) & $=\mathbf{1 . 9 4 0}$ \\
& GIF (Australia) & $\mathbf{0 . 5 6 4}$ & ESJI (KZ) & $=\mathbf{3 . 8 6 0}$ & IBI (India) & $\mathbf{4 . 2 6 0}$
\end{tabular}

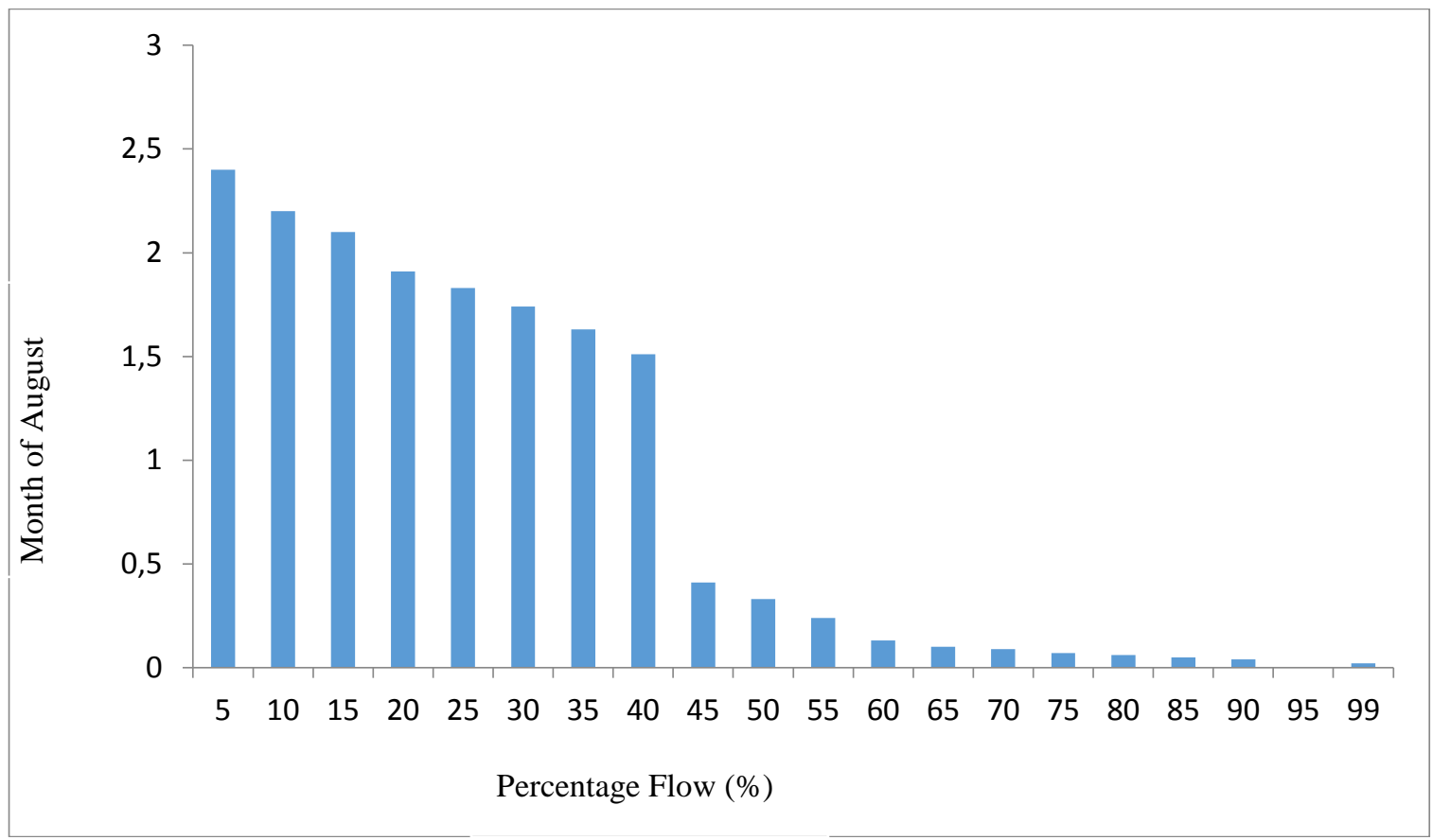

Figure 7 - Flow rate for August.

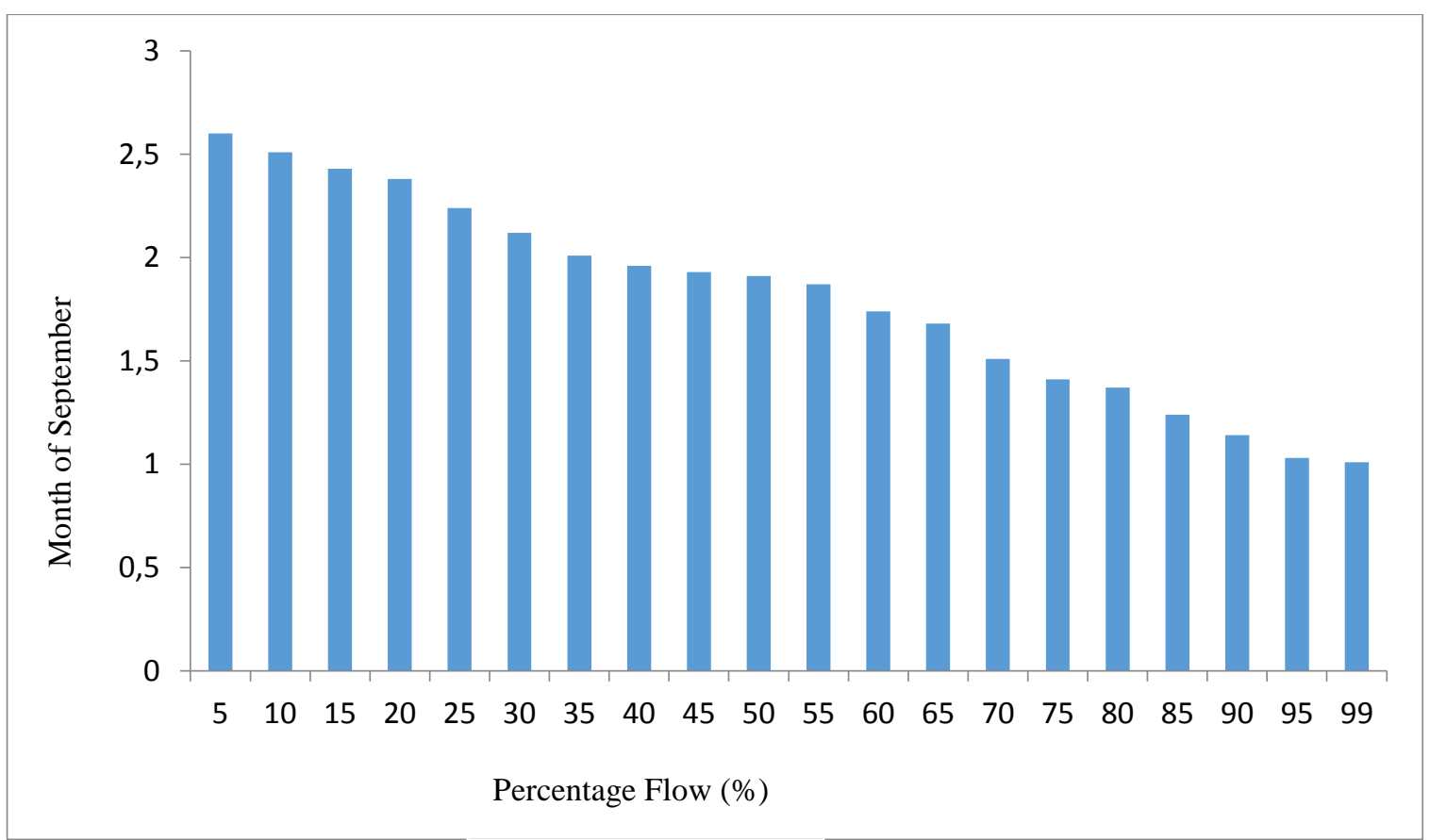

Figure 8 - Flow rate for September. 


\begin{tabular}{|c|c|c|c|c|c|c|}
\hline Impact Factor: & $\begin{array}{l}\text { ISRA (India) } \\
\text { ISI (Dubai, UAE } \\
\text { GIF (Australia) } \\
\text { JIF }\end{array}$ & $\begin{array}{l}=1.344 \\
=0.829 \\
=0.564 \\
=1.500\end{array}$ & $\begin{array}{l}\text { SIS (USA) } \\
\text { PИНЦ (Russia) } \\
\text { ESJI (KZ) } \\
\text { SJIF (Morocco) }\end{array}$ & $\begin{array}{l}=0.912 \\
=0.234 \\
=3.860 \\
=2.031\end{array}$ & $\begin{array}{l}\text { ICV (Poland) } \\
\text { PIF (India) } \\
\text { IBI (India) }\end{array}$ & $\begin{array}{l}=6.630 \\
=1.940 \\
=4.260\end{array}$ \\
\hline
\end{tabular}

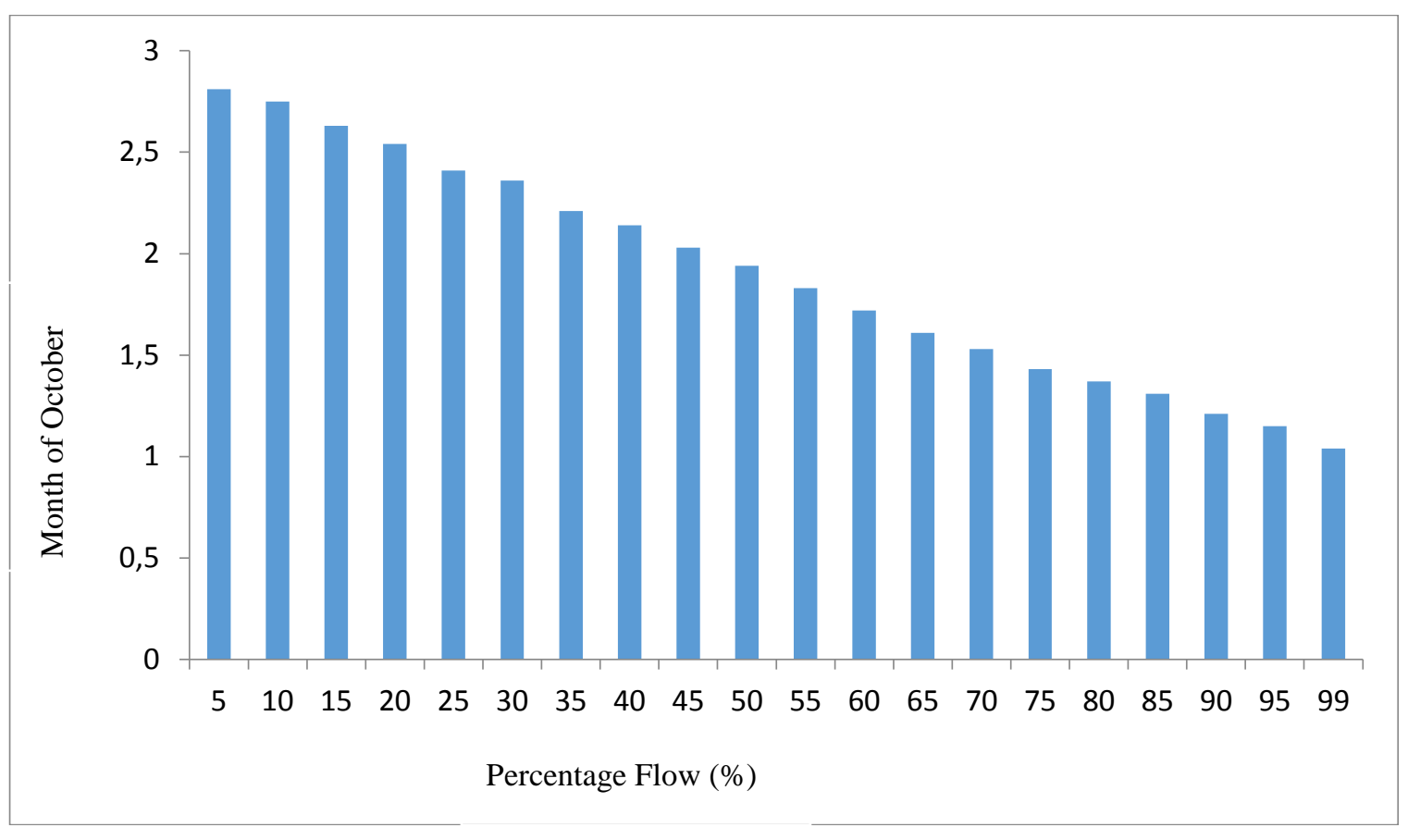

Figure 9 - Flow rate for October.

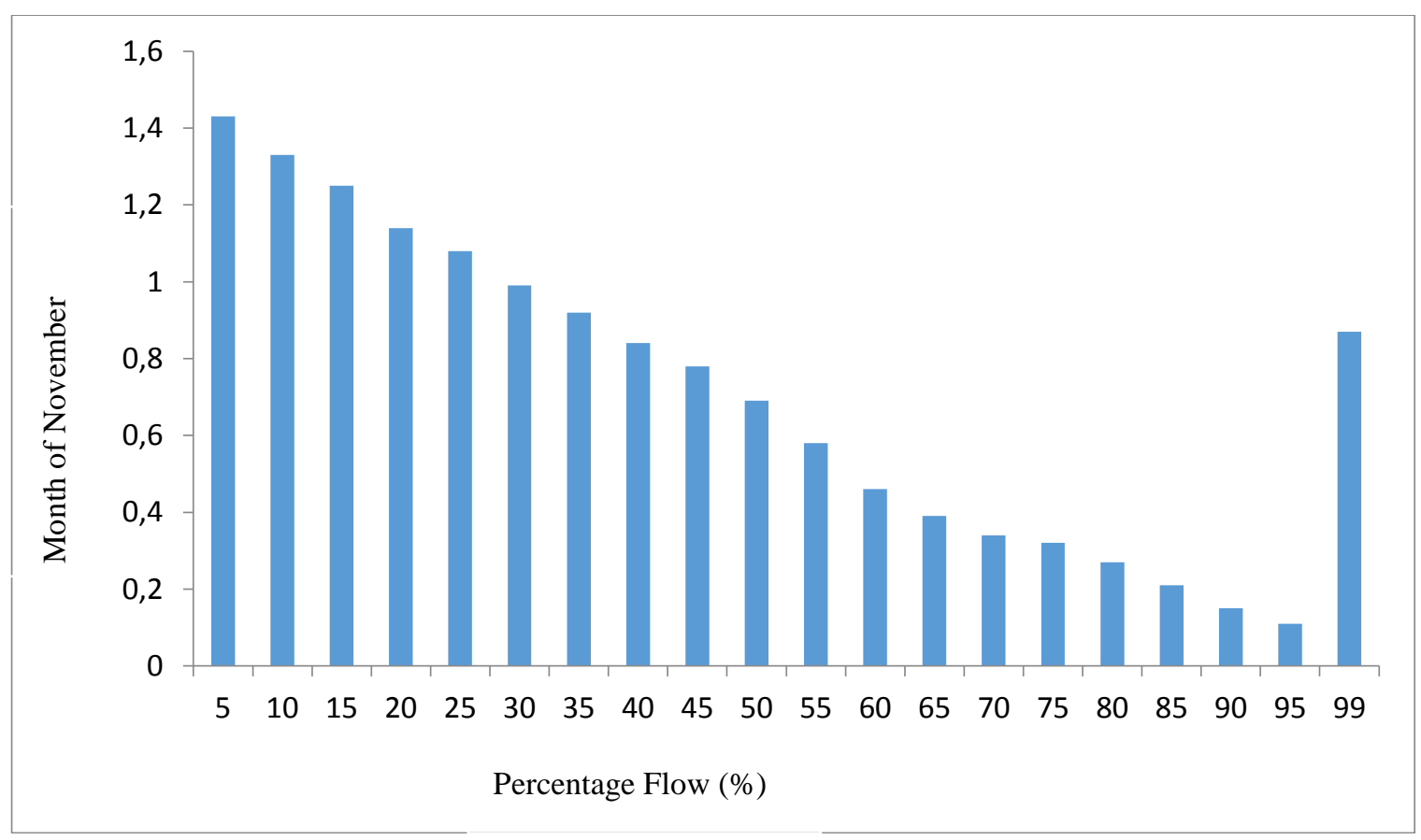

Figure 10 - Flow rate for November. 


\begin{tabular}{l|lr|ll|ll} 
& ISRA (India) & $=\mathbf{1 . 3 4 4}$ & SIS (USA) & $=\mathbf{0 . 9 1 2}$ & ICV (Poland) & $=\mathbf{6 . 6 3 0}$ \\
Impact Factor: & ISI (Dubai, UAE) $=\mathbf{0 . 8 2 9}$ & PUHI (Russia) & $=\mathbf{0 . 2 3 4}$ & PIF (India) & $=\mathbf{1 . 9 4 0}$ \\
& GIF (Australia) & $=\mathbf{0 . 5 6 4}$ & ESJI (KZ) & $=\mathbf{3 . 8 6 0}$ & IBI (India) & $\mathbf{4 . 2 6 0}$ \\
& JIF & $\mathbf{1 . 5 0 0}$ & SJIF (Morocco) & $\mathbf{2 . 0 3 1}$ & & \\
\hline
\end{tabular}

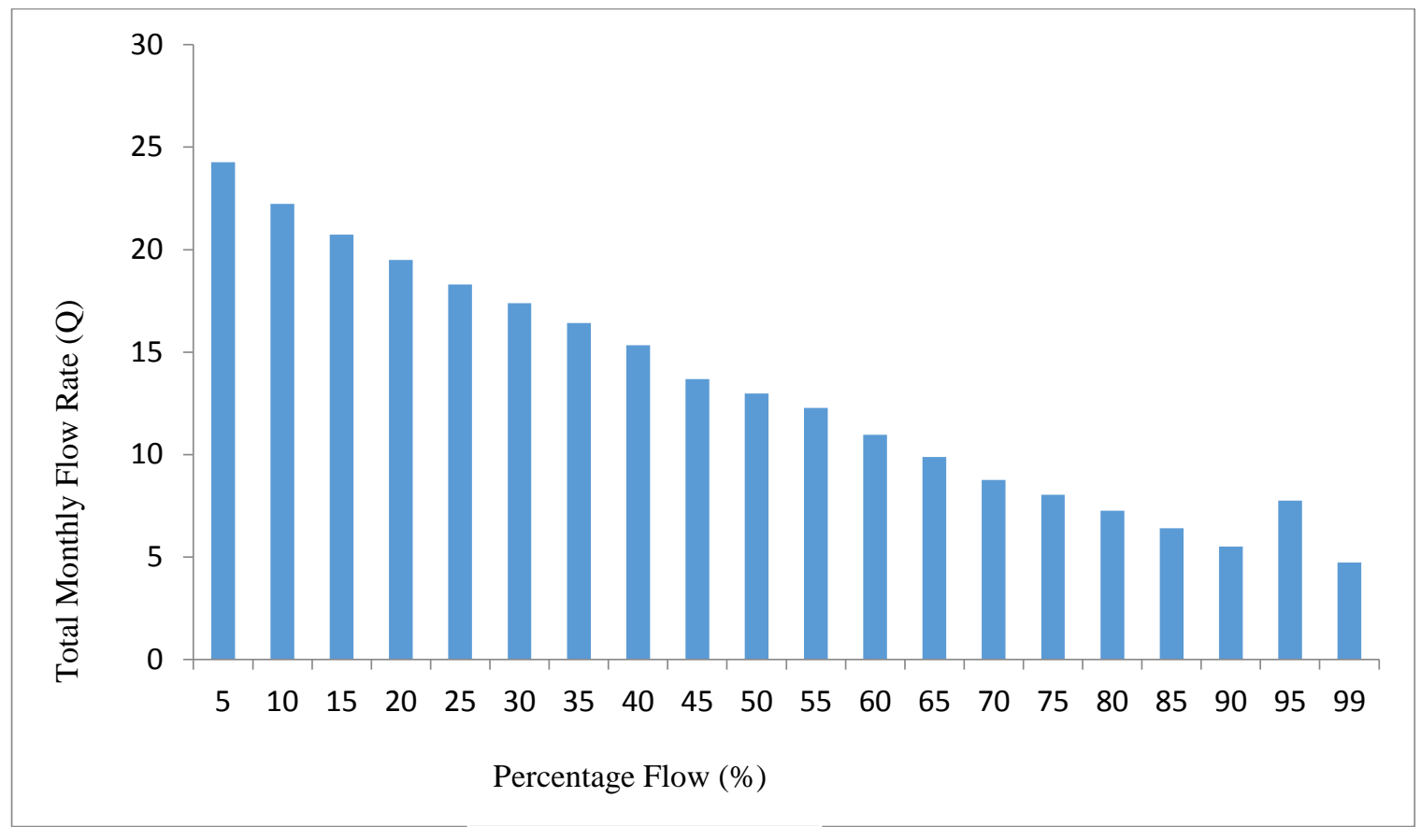

Figure 11 - Total Monthly Flow Rate.

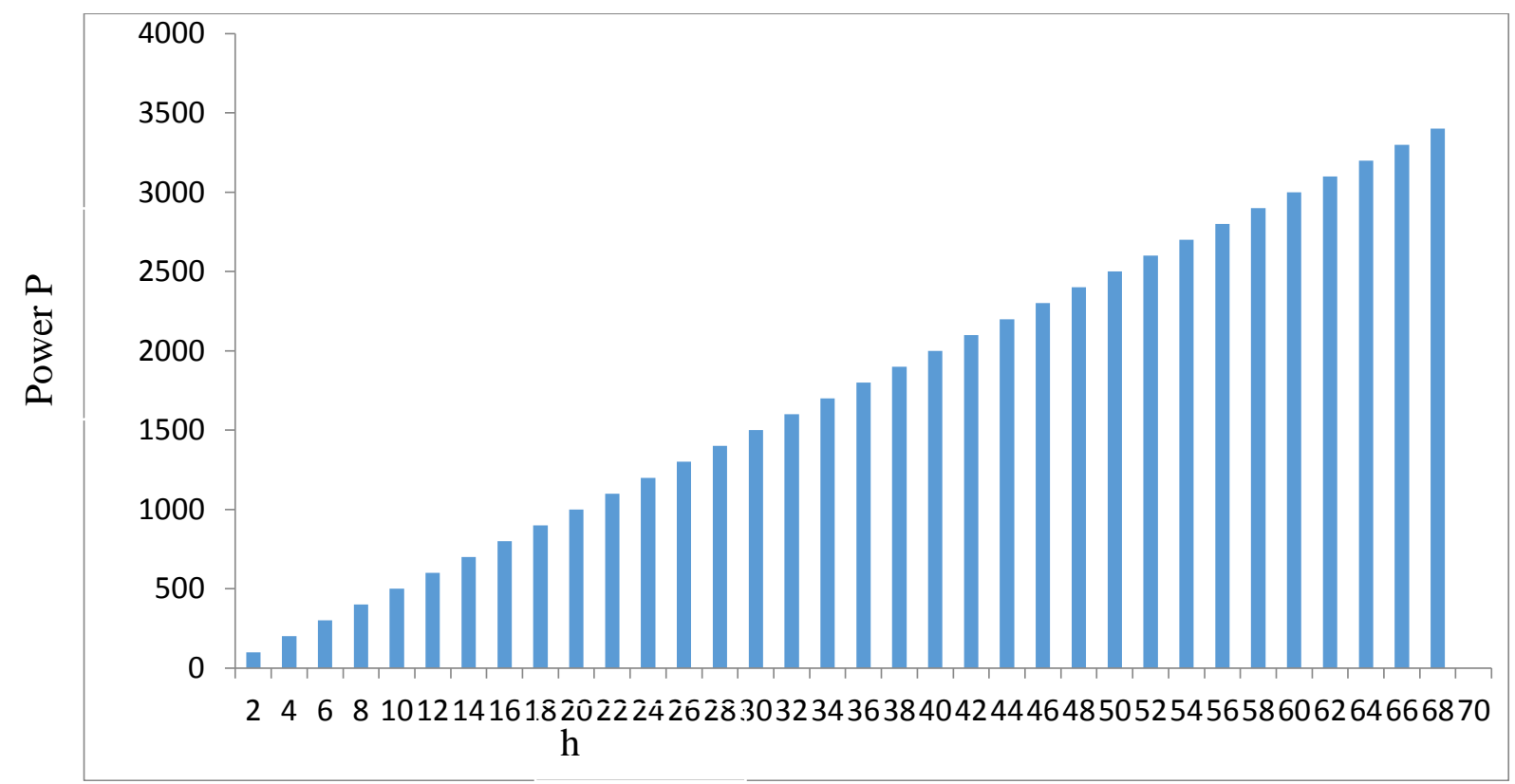

Figure 12 - Variation of the power with the falling height $h$. 


\begin{tabular}{l|lrl|l|ll} 
& ISRA (India) & $=\mathbf{1 . 3 4 4}$ & SIS (USA) & $=\mathbf{0 . 9 1 2}$ & ICV (Poland) & $=\mathbf{6 . 6 3 0}$ \\
Impact Factor: & ISI (Dubai, UAE) $=\mathbf{0 . 8 2 9}$ & PUHL (Russia) $=\mathbf{0 . 2 3 4}$ & PIF (India) & $=\mathbf{1 . 9 4 0}$ \\
& GIF (Australia) & $\mathbf{0 . 5 6 4}$ & ESJI (KZ) & $=3.860$ & IBI (India) & $=\mathbf{4 . 2 6 0}$ \\
& JIF & $\mathbf{1 . 5 0 0}$ & SJIF (Morocco) & $=\mathbf{2 . 0 3 1}$ & & \\
\hline
\end{tabular}

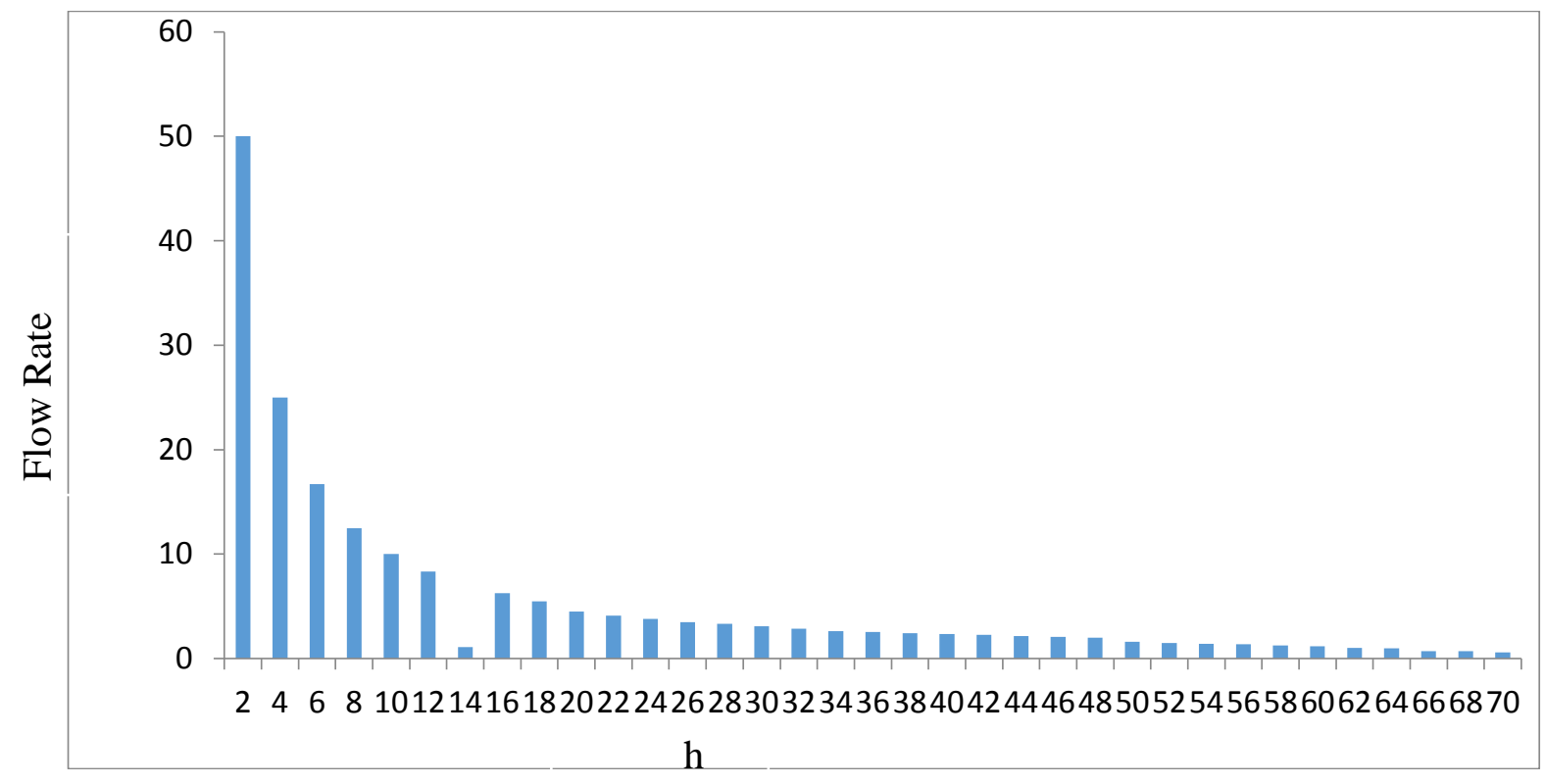

Figure 13 - Variation of flow rate with the falling height $h$.

\subsection{Conclusion}

A linear flow rate model for retrofitting of dam for hydroelectric power generation has been developed.

The model development started with the use of power available from falling water as input parameter with simulation carried out and coded in MATLAB.
The measured water level fluctuates throughout the study periods, the percentage flow rate of the dam increases as the monthly flow rate decreases.

The result of the linear model shows that there exist a linear correspondence between the theoretical power and the falling height of water in the dam while the flow rate was held constant at about $50 \mathrm{~m}^{3} / \mathrm{s}$.

\section{References:}

1. Aderibigbe DA (2009) "The role of independent power production (IPP) in meeting power demand in Nigeria", International Workshop on Promoting Coal for Power Generation. Nike Lake Resort, Enugu, Department of Environment, Water, Heritage and the Arts DEWHA, p. 32-51.

2. Atlason RS, Unthorsson R (2014) "Energy return on investment of hydroelectric power generation calculated using a standardized methodology", Renewable Energy: An International Journal, Volume 3, Number 6, p. 364-370.

3. Bergkamp G, Dugan P, McNeely J (2000) "Dams, ecosystem functions and environmental restoration", World Commission on Dams, Available: http://www.dams.org. (Accessed: 10.06.2017).

4. Cada G, Loar J, Garrison L, Fisher R, Neitzel D (2006) "Effort to reduce mortality to hydroelectric turbine-passed fish: location and quantifying damaging shear stresses", Environmental Management, Volume 37, Number 6, p. 898-906.

5. Chen ZJ (2006) "Studies on the long effective mechanism for constructing small scale water engineering development in rural areas", Chinese Journal of Agricultural Resources and Regional planning, Volume 27, Number 2, p. 45-49.

6. Cross W, Baxter CV, Donne KC, Rosi-Marshall EJ, Kennedy TA, Hall,Jr RO, Wellard Kelly HA, Rogers RS (2011) "Ecosystem ecology meets adaptive management: food web response to a controlled flood on the Colorado River", Glen Canyon. Ecological Applications. Volume 6, Number 21, p. 20-33.

7. Deng Z, Richmond MC, Mueller RP, Duncan JP, Carlson TJ (2005) "Laboratory study of biological response of juvenile salmon subjected to turbulent shear flows", Proceedings 


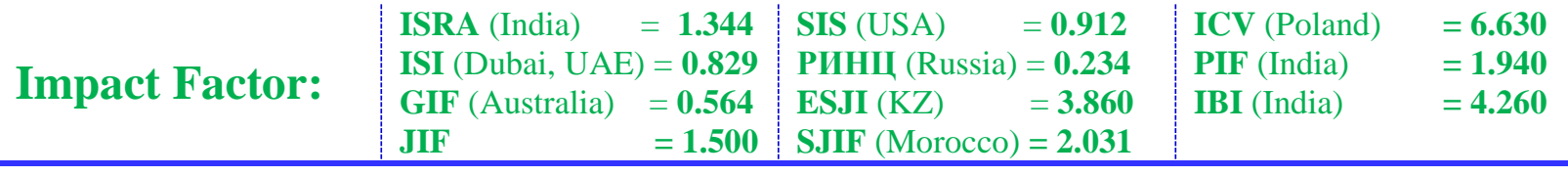

of Waterpower XIV, HCI Publications, Austin, Texas, p. 15-19.

8. Egre D, Milewski JC (2002) "The diversity of hydropower projects", Energy Policy, Volume 6, Number 8, p. 77-91.

9. Eskew A, Price S, Dorcas M (2012) "Effects of river-flow regulation on anuran occupancy in abundance in riparian zones", Conservation Biology, Volume 2, Number 9, p.33-41.

10. Francis JRD (1971) "A Textbook of Fluid Mechanics for Engineering Students, 3rd Edition, Arnold, London, p. 33-71.

11. Francis JRD (2007) "A textbook of fluid mechanics for engineering students", 3rd Edition, Arnold, London, p. 33-64.

12. Harvey A (1993) "Micro-hydro design manual: a guide to small-scale water power schemes", Intermediate Technology Development Group London, Stylus Publication, p.288-291.

13. Harvey A (2003) "Micro-hydro design manual: a guide to small-scale water power schemes", Intermediate Technology Development Group London, Stylus Publication, p.288-301.

14. Hibbs DE, Gulliver JS (1997) "Prediction of effective saturation concentration at spillway plunge pools", Journal of Hydraulic Engineering, Volume 123, Number 11, p. 940949.

15. Hidalgo IG, Fontane D, Lopes J, Andrade J, de Angelis A (2014) "Efficiency curves for hydroelectric generating units", Journal Of Water Resources Planning \& Management, Volume 1, Number 14, p. 86-91.

16. Isagirre O (2013) "Nutrient uptake in a stream affected by hydropower plants: comparison between stream channels and diversion canals", Hydrobiologia Journal, Volume 4, Number 6, p. 32-51.

17. Kao DT, Wu YL, Huang SJ, Gao FF (2006) "Analytical and experimental research and development of the updraft free-exit-flow hydropower turbine system", The $2^{\text {nd }}$ International Forum on Hydropower for Today, Hangzhou, China, p. 39-47.

18. Kao DT, Wu YL, Huang SJ, Gao FF (2007) "Industrial application of an innovative ecoenvironmental friendly hydropower turbine", Water power XV-HCL, p. 116-139.

19. Kao DT, Yuan GL, Chen X, Liu SH (2008) "New frontiers and opportunities for hydropower:- a broad vision of sustainable energy to better serve future global need", HydroVision08, Sacramento CA USA, Publication, p. 158-169.

20. Kubecka J, Matena J, Hartvich P (1998) "Adverse ecological effects of small hydropower stations in the Czech Republic", Regulated Rivers: Research and Management, Volume 4, Number 2, p. 22-29.
21. Kumar D, Katoch SS (2014) "Sustainability indicators for run off river (RoR) hydropower projects in hydro rich regions of India", Renewable and Sustainable Energy Reviews, Volume 3, Number 2, p. 101-108.

22. Maher P, Smith NPA, Williams AA (2002) "Assessment of pico-hydro as an option for off-grid electrification in Kenya", Renewable Energy, Volume5, Number 3, p. 29-43.

23. Margeta J, Đurin B (2014) "Hydrological and hydro-energy indicators of the hybrid energy system using solar and pumps Storage hydroelectric plant", International Journal of Sustainable Energy, Volume 4, Number 3, p. 827-841.

24. McGinnis DF, Ruane RJ (2007) "Development of the discrete-bubble Model for turbine aeration systems", Water Power XV-HCL, p. 128-137.

25. Nilsson C (1981) "Effects of stream regulation on riparian vegetation", Regulated Rivers: Second International Symposiums on Regulated Rivers, Oslo, Norway, Ed. Lillehammer, Albert and Saltveit, Publisher, $2^{\text {nd }}$ Edition. New York City: Columbia U, p. 93-106.

26. Olden JD, Naiman RJ (2010) “"Incorporating thermal regimes into environmental flow assessments: modifying dam operations to restore freshwater ecosystems integrity", Freshwater Biology Journal, Volume 5, Number 5, p.86-97.

27. Paish O (2002) "Small hydropower: technology and current status", Renewable and Sustainable Energy Reviews, Volume 5, Number 6, p. 537-556.

28. Sambo AS (2009) "Prospect of coal for power generation in Nigeria", A paper at the international Workshop on Promotion of Coal for Power Generation, Enugu, p. 26-43.

29. Schiermeier Q, Tollefson J, Scully T, Witze A, Morton O (2008) "Energy alternatives: electricity without carbon. Nature, volume 5, Number 4, p. 816-821.

30. Tarlock D (2012) "Hydro Law and the future of hydroelectric power generation in the United States', Vanderbilt Law Review. Volume 6, Number 5, p. 723-739.

31. Urban AL, Gulliver JS, Johnson DW (2008) "Modeling total dissolved gas concentration downstream of spillways", Journal of Hydraulic Engineering, Volume 134, Number 5, p. 550561.

32. Yang SL, Zhang J, Xu XJ (2007) "Influence of the three Gorge dams on downstream delivery of sediment and its environmental implications", Yangtze River, Geophys. Res. Lett, Volume 3, Number 2, p. 11-21. 